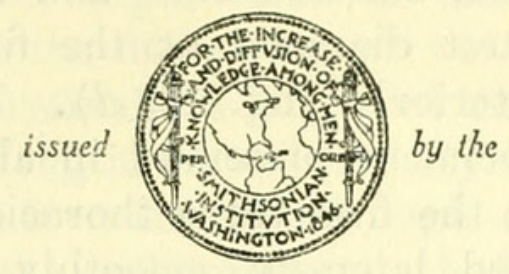

SMITHSONIAN INSTITUTION

U. S. NATIONAL MUSEUM

\title{
A NEW HARPACTICOID COPEPOD FROM THE GILL CHAMBERS OF A MARSH CRAB
}

\section{By Arthur G. Humes}

WhILE studying the parasites of crabs at the Louisiana State University Marine Laboratory at Grand Isle, La., the writer collected specimens of a previously undescribed copepod belonging to the genus Cancrincola (Copepoda: Harpacticoida: Ameiridae). This genus was first recognized by Wilson (1913), who designated his newly described species, Cancrincola jamaicensis, from the gills of the white land crab, Cardisoma guanhumi Latreille, at Montego Bay, Jamaica, as genotype. In 1930 Pearse described a second species, Cancrincola witsoni, from the gills of the red land crab, Sesarma haematocheir (de Haan), and of the littoral crab, Sesarma pictum (de Haan), at Aburatsubo, near Misaki, Japan. A few specimens of $C$. jamaicensis Wilson were collected by Pearse (in Wilson, 1935) from the branchial cavity of the spider crab, Microphrys bicornutus (Latreille), at the Dry Tortugas, Fla. The gill chambers of two adult marsh crabs, Sesarma reticulatum (Say), a male and a female, collected at Grand Isle, La., on June 14, 1940, contained about 50 copepods, named and described as follows:

CANCRINCOLA PLUMrPES, ncw species

\section{Figure 18}

Type material from the gill chamber of Sesarma reticulatum, at Grand Isle, La. Holotype, female, U. S. N. M. No. 79347; allotype, U. S. N. M. No. 79348; and 20 paratypes including both sexes, U S. N. M. No. 79349. 
Female-Body slender, between four and five times as long as wide, cylindrical, greatest diameter at the first thoracic segment, gradually tapering posteriorly (fig. 18, d). Thorax and abdomen arched ventrally in specimens preserved in alcohol. Cephalic segment nearly as long as the first three thoracic segments combined. Cephalon well developed laterally, smoothly truncate posteriorly, rather broadly rounded anteriorly, posterior half of dorsum with two pairs of very small setae, the posterior pair slightly larger; rostrum very small, elongated-oval, with two minute curved setae on the anterior end.

First segment of the 6-segmented thorax rather indistinctly separated from the cephalic segment, the dorsum shorter than either of the following two dorsa and bearing a pair of minute setae; another small seta at the origin of both basipods. Second thoracic segment with a pair of setae on the dorsum, two pairs laterally and two pairs at the origin of the basipods, all five setae on one side more or less linear and well separated from one another. Third segment with similar setae, but with one additional lateral pair, making six pairs in all; the dorsum a little shorter than that of the second segment. Fourth segment similar to second. Fifth segment with shortest dorsum of all body segments, located at the center of the body arch and often telescoped with the adjacent dorsa; three pairs of setae, one on the dorsum, one laterally, and one near the base of the fifth legs. Sixth segment of the thorax with a pair of setae on the dorsum and another pair on the posterior lateral areas; a single genital opening on the ventral side.

Abdomen 4-segmented, segments narrowed but of about the same length as the third and fourth thoracic segments, dorsa quadrangular rather than rectangular. First abdominal segment with two pairs of setae like those on the last thoracic (genital). Second with a pair of setae on the dorsum, a vertical row of about 11 setae on the lateral areas and a ventral transverse band of setae on the posterior half. Third segment with a pair of setae on the dorsum, on both sides a dorsolateral vertical row of seven setae and a lateral vertical row of six setae, with a ventral transverse row of setae on the posterior half. Fourth abdominal segment with slightly shorter dorsum than the preceding ones, segment deeply incised at the center, without anal operculum; a short transverse ventral row of setae on the anterior part, a pair of setae on the dorsum, and on both sides a row of setae on the dorsal, lateral, and ventral aspects of the posterior part of the segment, adjacent to the origin of the anal laminae.

Anal laminae much shorter than the terminal segment and stout, both armed on the lateral aspect with three large setae (the middle one one-half as long as the other two) in a vertical row, at the distal 
lateral angle a seta bearing a comb of three teeth, on the medial distal angle two setae the dorsal one of which is set upon a singlejointed pedicel, and terminally a long anal seta, which is about threequarters of the body length, curved distally toward the midline and finely plumose. At the ventral distal angle of the anal laminae one or two very minute setae and anterior to the base of the most ventral of the three lateral setae a vertical row of three very small setae.

Anterior antennae (fig. 18, c) with eight similar podomeres, joints not strongly chitinized, numerous setae ventrally, a tuft of setae terminally, two setae on the dorsal side of the seventh podomere. On the distal ventral angle of the fourth podomere a dimerous athetask slightly longer than the distal four podomeres, the distal part about one-third the length of the whole.

Posterior antennae (fig. 18, $b$ ) somewhat shorter than the anterior pair, with two podomeres and monomerous exopod; a single spine on the inner margin of the proximal podomere; cylindrical exopod attached near the center of the outer margin of the first podomere, terminating in three setae the longest of which is posterior and the shortest anterior. Distal podomere about two-thirds the length of the proximal one, armed on the inner side with two rows of four dentiform setae and on the outer side with two short setae; terminally with seven setae, the inner three pectinate on the distal two-thirds and shorter than the adjacent three outer ones, which are pectinate only at their centers; outer seta short, pectinate, with longer and finer teeth; an eighth spiniform seta at the base of the second inner seta.

Mandibles (fig. 18, $l$ ) minute, about $15 \mu$ long, the outer ramus very small, simple, monomerous, terminating in three short, blunt, spinelike processes; inner ramus flattened into a concave lamina or blade, armed distally with a row of minute setae. First maxillae (fig. $18, m$ ) with a cylindrical monomerous exopod bearing two setae terminally and three filamentous setae on the inner side; endopod similar, with four setae terminally; a single seta on the basipod lateral to the base of the exopod. Second maxillae (fig. 18, $h$ ) with a thickset exopod terminating in a long, curved claw pectinate on the distal half of its inner margin; two small setae on the outer side of the distal end of the exopod; endopod cylindrical, shorter than the exopod, with two setae on the distal end. Maxillipeds (fig. 18, e) with two podomeres, the first short and stout, the second longer and swollen with a long, slender terminal claw pectinate on the concave side and curved to fit the side of the second podomere; a longitudinal row of six to eight very fine setae near the distal end of the first podomere.

First four pairs of legs biramose, somewhat flattened, the first pair of legs adapted for clasping, the following three for swimming, the 
fifth pair much modified. Basipod of the first pair armed on the outer side with a proximal transverse row of 11 minute setae, a central row of nine larger though similar setae, and at the base of the exopod a large pectinate seta and a row of much smaller ones; at the base of the endopod similar setae. Exopod (fig. 18, k) of three similar podomeres, each armed with a stout pectinate seta at the outer distal angle and more proximally on the outer side with a row of four shorter setae; at the distal borders of the first two podomeres a row of four or five dentiform setae; on the central inner edge of the second podomere two very small setae and distally a larger plumose seta; terminally on the third podomere a row of four setae, the inner two longer than the whole exopod and pectinate centrally, the outer two about half as long or less and pectinate over nearly the whole length. Endopod nearly twice the length of the exopod, with two podomeres, the proximal one a little more than four times the length of the distal one and armed on the inner side with a central row of six setae, distal to which a single much longer plumose seta, armed on the outer side with a central row of six setae and two minute setae at the outer distal angle; distal podomere with a row of seven minute setae on the inner side and a row of three larger setae terminally, the middle one being twice the length of the other two and pectinate centrally, the inner one plumose, the outer one pectinate throughout.

Basipod of the second pair of legs with only the distal rows of setae at the bases of the exopod and endopod. Exopod (fig. 18, i) a little longer than the endopod, both with three similar podomeres. Exopod with stout pectinate seta at the outer distal angles of the podomeres, proximal to which there is a row of four minute setae, with five or six additional very small setae along the distal border of the first two podomeres; second podomere having on the inner side two small setae, distal to which a much longer plumose seta; third podomere with five terminal setae, the inner three about twice as long as the exopod and plumose, except the outer one of the group, which is plumose on the inner side and pectinate on the outer side; the outer two pectinate setae only one-third or less the length of the inner ones. Endopod with four to six small setae on the outer sides and a longer plumose seta at the distal inner angles of the three podomeres; on the third podomere three terminal setae, the outer one short, stout and pectinate, the inner two a little more than twice the length of the endopod and plumose.

Third basipod like the second; both rami of the third pair of legs with three similar podomeres; exopod like that of the second pair of legs, except that it is longer than the endopod and the minute setae on the inner side of the second podomere are absent; endopod 


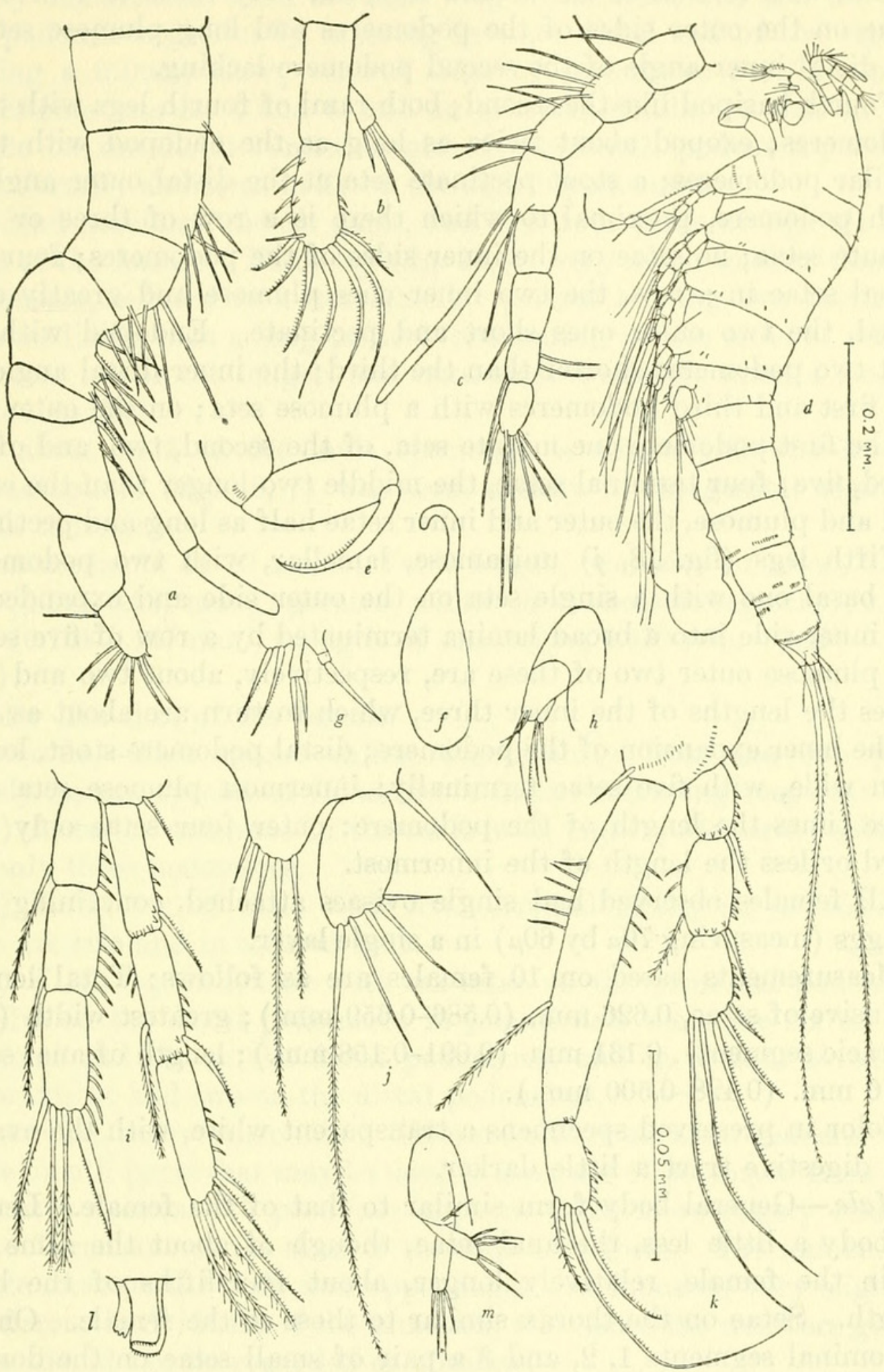

Figure 18.-Cancrincola plumipes, new species: $a$, Anterior antenna, male; $b$, posterio; antenna, female; $c$, anterior antenna, female; $d$, female, lateral view; $e$, maxilliped, female $f$, spermatophore, male; $g$, fifth leg, male; $h$, second maxilla, female; $i$, second leg, fer male; $j$, fifth leg, female; $k$, first leg, female; $l$, mandible, female; $m$, first maxilla, female. All figures were drawn with aid of a camera lucida. The $0.2 \mathrm{~mm}$. scale applies only to $d$; the $0.05 \mathrm{~mm}$. scale near $k$ applies to all the other figures. 
similar also to that of the second legs, but only three to four small setae on the outer sides of the podomeres and long plumose seta at the distal inner angle of the second podomere lacking.

Fourth basipod like the second; both rami of fourth legs with three podomeres; exopod about twice as long as the endopod with three similar podomeres; a stout pectinate seta at the distal outer angle of each podomere, proximal to which there is a row of three or four minute setae; no setae on the inner sides of the podomeres; four terminal setae in a row, the two inner ones plumose and greatly elongated, the two outer ones short and pectinate. Endopod with the first two podomeres shorter than the third; the inner distal angles of the first and third podomeres with a plumose seta; on the outer side of the first podomere one minute seta, of the second, two, and of the third, five; four terminal setae, the middle two longer than the endopod and plumose, the outer and inner setae half as long and pectinate.

Fifth legs (fig. 18, $j$ ) uniramose, lamellar, with two podomeres, the basal one with a single seta on the outer side and expanded on the inner side into a broad lamina terminated by a row of five setae; the plumose outer two of these are, respectively, about two and four times the lengths of the inner three, which in turn are about as long as the inner expansion of the podomere; distal podomere stout, longer than wide, with five setae terminally; innermost plumose seta over three times the length of the podomere; outer four setae only onethird or less the length of the innermost.

All females observed had single ovisacs attached, containing 2 to 11 eggs (measuring $70 \mu$ by $60 \mu$ ) in a single layer.

Measurements based on 10 females are as follows: Total length, exclusive of setae, $0.626 \mathrm{~mm}$. $(0.586-0.659 \mathrm{~mm}$.) ; greatest width (first thoracic segment), $0.131 \mathrm{~mm}$. (0.091-0.158 mm.) ; length of anal setae, $0.476 \mathrm{~mm}$. (0.428-0.500 mm.).

Color in preserved specimens a transparent white, with the ovaries and digestive tract a little darker.

Male.-General body form similar to that of the female. Length of body a little less, the anal setae, though of about the same size as in the female, relatively longer, about four-fifths of the body length. Setae on the thorax similar to those in the female. On the abdominal segments 1,2 , and 3 a pair of small setae on the dorsum and a lateral and ventral transverse row of still more minute setae in the posterior part of the segment; terminal segment and anal laminae with setae as in the female.

Anterior antennae (fig. 18, a) with eight podomeres of different sizes, joints more heavily chitinized than in the female, first two podomeres equal, third shorter on the dorsal side, fourth largest, rounded dorsally and concave ventrally, fifth shortest, rather indis- 
tinctly demarcated, sixth about as long as the first, this and the last two podomeres gradually tapering in size; distal end of the eighth bearing a minute claw; ventral sides of podomeres 1 to 6 setose, a pectinate seta on 4 and 6 , and an athetask similar to that in the female on the distal ventral angle of the fourth podomere; a few setae dorsally and terminally on the eighth podomere.

Second antennae, mouth parts, and first four pairs of legs all like those of the female. Fifth leg (fig. 18, $g$ ) very much smaller than in the female, reduced to a low lamellar process bearing two pectinate setae medially, then a long pedicel terminating in two setae of which the inner one is the longer, and outermost a seta set upon a singlejointed pedicel.

In about half of the male specimens a single yellowish-brown spermatophore (fig. 18, $f$ ) was seen, usually in the genital segment (sixth thoracic).

Measurements of 10 males: Total length, exclusive of setae, 0.583 $\mathrm{mm}$. (0.545-0.621 mm.) ; greatest width (first thoracic segment), 0.219 $\mathrm{mm}$. (0.104-0.147 mm.); length of anal setae, $0.470 \mathrm{~mm}$. (0.400-0.524 mm.).

Color like that of the female.

Remarks.-This species differs significantly from the two previously known species of Cancrincola in the following respects:

(1) Anterior antennae in the male with eight podomeres; wilsoni has only three podomeres.

(2) Fifth leg of male with five terminal setae; in jamaicensis there are two and in wilsoni four.

(3) Fifth leg of female with six setae on the proximal podomere and five on the distal podomere; in jamaicensis there are six on the proximal and six on the distal podomeres, and in wilsoni seven on the proximal and two on the distal podomeres.

There are many other minor differences in setal arrangements and in the mouth parts that may be used to separate $C$. plumipes from the other two species. $C$. plumipes appears to be more closely related to the Jamaican species than to the Japanese form. The number of minute setae on the body and appendages was found to vary slightly in different individuals of the same sex, and hence the numbers given above should not be regarded as absolute.

Members of this genus have been found in the gill chambers of both terrestrial and aquatic crabs. They show little modification for a parasitic way of life and have retained the ability to swim freely. The life cycles of these species, though unknown at present, are probably intimately connected with the molting of the crabs and their migrations into the sea for food getting or for development and hatching of their eggs. 


\section{LITERATURE CITED}

Pearse, Arthur Sperry.

1930. Parasites of Japanese Crustacea. Annot. Zool. Jap., vol. 13, pp. 1-8. Wilson, Charies Branch.

1913. Crustacean parasites of West Indian fishes and land crabs, with descriptions of new genera and species. Proc. U. S. Nat. Mus., vol. 44, pp. 189-277.

1935. Parasitic copepods from the Dry Tortugas. Papers from the Tortugas Laboratory, vol. 29, pp. 329-347. 386 


\section{$2 \mathrm{BHL}$ Biodiversity Heritage Library}

Humes, Arthur G. 1941. "A new harpacticoid copepod from the gill chambers of a marsh crab." Proceedings of the United States National Museum 90(3110), 379-386. https://doi.org/10.5479/si.00963801.90-3110.379.

View This Item Online: https://www.biodiversitylibrary.org/item/32375

DOI: https://doi.org/10.5479/si.00963801.90-3110.379

Permalink: https://www.biodiversitylibrary.org/partpdf/14464

\section{Holding Institution}

Smithsonian Libraries

\section{Sponsored by}

Smithsonian

\section{Copyright \& Reuse}

Copyright Status: NOT_IN_COPYRIGHT

Rights: https://www.biodiversitylibrary.org/permissions/

This document was created from content at the Biodiversity Heritage Library, the world's largest open access digital library for biodiversity literature and archives. Visit BHL at https://www.biodiversitylibrary.org. 